Review

\title{
SPIKE MORPHOLOGY GENES IN WHEAT SPECIES (TRITICUM L.)
}

\author{
Irina Konopatskaia, Valeriya Vavilova, Alexandr Blinov, and Nikolay P. Goncharov\#
}

The Federal Research Center Institute of Cytology and Genetics SB RAS, Prospekt Lavrentyeva, 10, Novosibirsk, 630090, RUSSIAN FEDERATION

\# Corresponding author: Nikolay P. Goncharov, e-mail: gonch@bionet.nsc.ru

Contributed by Nikolay P. Goncharov

The review examines the state of knowledge on genes that control the architectonics of wheat plant (spike morphology). It is shown that molecular genetic studies, which have been recently started, allow to find both the orthologous genes from relative species of wheat (barley, rye, etc.) and genes that were not previously used for breeding. Use of these genes for further breeding allows to produce modern wheat commercial cultivars.

Key words: spike morphology, plant architecture, gene, wheat species, Triticum.

\section{INTRODUCTION}

Wheat species of the genus Triticum L. are members of the Triticeae Dum. tribe of the Poaceae Barn. family and represent the world's most important monocotyledenous cereals (Anonymous, 2015). The genus Triticum consists of 29 species divided into five sections Monococcon Dum., Dicoccoides Flaksb., Timopheevii A. Filat. et. Dorof., Triticum L. and Compositum N. P. Gontsch. (Goncharov, 2011). The first four sections listed above were based on the species ploidy level, cytoplasm type and genome composition, while the Compositum section includes man-made species. Depending on the level of ploidy, the natural Triticum species are diploids ( $2 n=14$, haploid genome: A), tetraploids ( $2 n=28$, haploid genome: BA or GA), hexaploids $(2 n=42$, haploid genome: BAD or GAD) or octoploids $(2 n=56$, haploid genome: BAGA or GABA) (Kimber and Sears, 1987; Goncharov et al., 2007a).

Presently, one diploid, three tetraploid, and two hexaploid species are cultivated under different climate conditions (Tadesse et al., 2016). Wheat is the oldest and most widely grown grain crop, which occupies about $17 \%$ of the crop acreage worldwide and provides $19 \%$ of the calories to the world's population (Anonymous, 2015). At present, wheat is the main food for about $40 \%$ of the world population, and the future demand for wheat is estimated to increase significantly. Bread (common) wheat Triticum aestivum L. has been commonly used for the production of bread, durum wheat $T$. durum Desf. for macaroni and semolina, while $T$. monococcum L., T. dicoccum (Schrank) Schuebl. and T. spelta $\mathrm{L}$. are groat crops.

The modern cultivated crops represent the result of domestication of wild ancestors by early farmers followed by the diversification and improvement for more than ten thousands of years (Gross and Olsen, 2010). Domestication is the process of genetic adaptation of wild species to human needs, typically including changes in appearance and lifestyle (Lenser and Theißen, 2013). According to archaeological data, the domestication of most cereals started 10-12 000 years ago and was completed about 3000-4000 years ago (Lev-Yadun et al., 2000; Doebley et al., 2006). The domestication of wheat started in the Fertile Crescent, the region partially covering the modern territory of Israel, Turkey, and Iraq (Glémin and Bataillon, 2009).

During the domestication and subsequent cultivation of wheat, new and improved cultivars were developed by selection in order to meet human demands: taste, yield, cultivation and harvest storage methods (Gepts, 2004). The set of traits acquired by species during the domestication was called the "domestication syndrome" (Hammer, 1984) and includes the reduction or loss of the ability of natural dispersal, the development towards compact growth habit, early maturity, reduction or loss of toxic compounds and other (for review see: Gross and Olsen, 2010) i.e. domestication alters the plant architecture. The improvement and diversification traits include selection for grain quality, color, shape, etc. (for review see: Gross and Olsen, 2010). There are no clear divisions between domestication, diversification and improvement traits and genes involved in their control. For example, $R c$ gene of rice is considered as both a domestication gene and an improvement gene (Gu et al., 2004; Sweeney, 2006).

The modern cultivated wheats differ from their wild relatives and progenitors by a set of morphological and physiological features including traits related to spike morphology, such as spike shape, treshability, and shattering. In this pa- 
per, we present current knowledge of the agronomically important spike morphology traits in wheat (subtribe Frumentaceae Dum., tribe Triticeae) and explore some of the recent findings in the area of identification of the genes underlying the spike morphology traits.

\section{SPIKE MORPHOLOGY TRAITS IN WHEAT SPECIES}

The spike is one of the most important parts of a wheat plant. It includes the reproductive organs, produces the seeds, and ensures dispersal of the mature grains. Spike morphology greatly affects breeding, harvest procedures and the yield. Spikes of wheat species differ in several morphological characteristics, including threshability, the presence or absence of awns, spike shape, spike shattering, spike branching and supernumerary spikelets spike (Fig. 1).

Threshability. Easy threshing ability is mainly dependent on the tenacity of the glumes covering the grains. The wild species possess hulled grains (syn. non free-threshing), which are covered by a tough glume that remains adhered to the grain after the threshing (Dorofeev and Korovina, 1979). Naked or free-threshing seeds of cultivated wheat

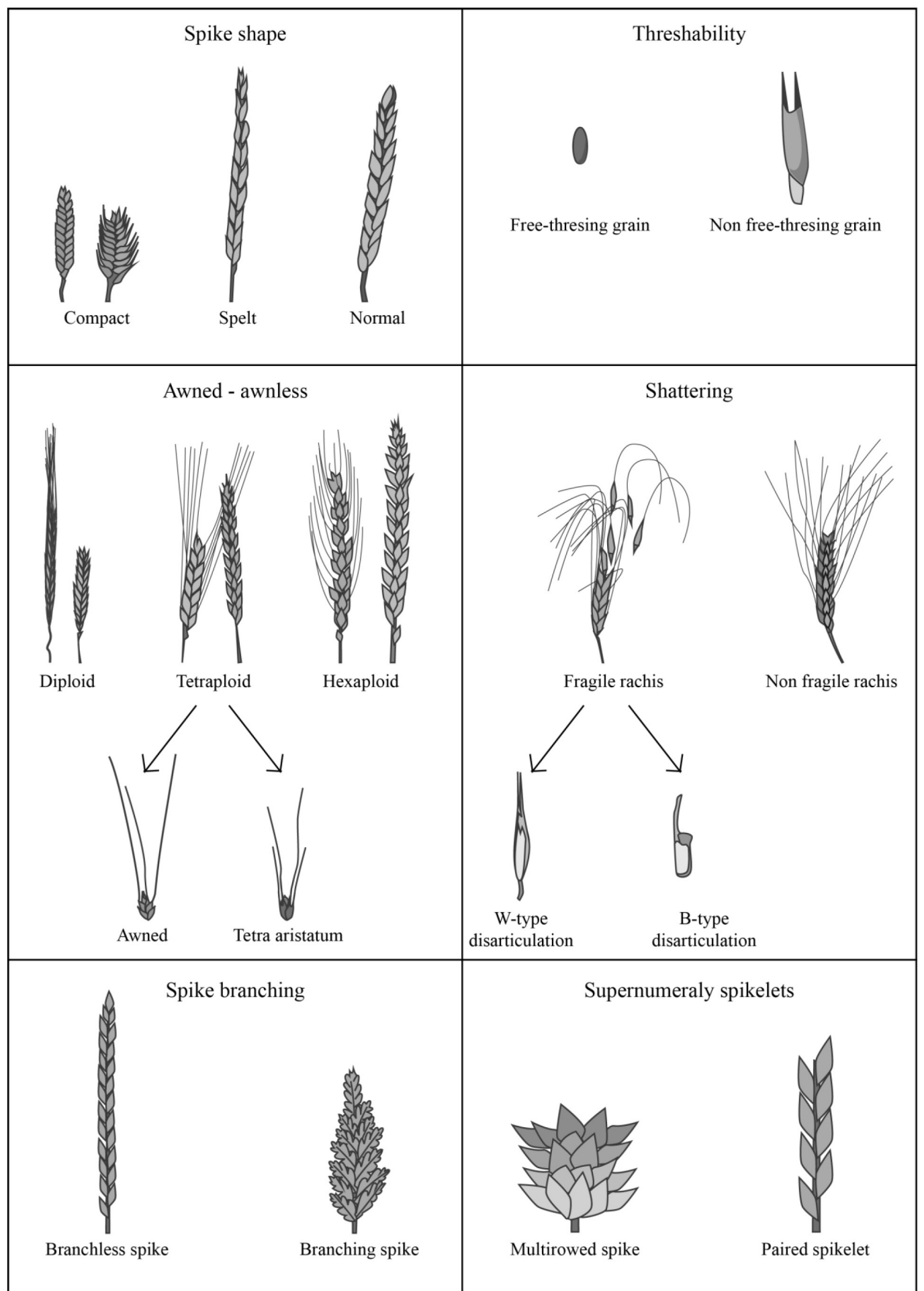

Fig. 1. Spike morphology traits in wheat species. *, for each ploidy level the awned (left spike) and awnless (right spike) phenotypes are presented. 
species are rounded by soft glumes which release during threshing (Fig. 1). Wheat varieties with free-threshing seeds appeared during domestication and significantly advanced the efficiency of the threshing process and led to wheat becoming a major crop all over the world (Zhang et al., 2011).

The presence or absence of awns. Awns are the threadlike extensions of the lemma. They have photosynthetic function, increase the assimilation of water, and may promote high yield of wheat grown under water-limited conditions (Reynolds and Tuberosa, 2008; Maydup et al., 2010) (Fig. 1). Several comparative studies of the grain yield advantage in awned and awnless lines gave conflicting results. The comprehensive investigation of Rebetzke et al. (2016) showed that awned near-isogenic lines are characterised by slightly greater grain yield due to increased kernel size and reduced screening. It was also demonstrated that awnless wheats with acceptable yield and quality have provide advantage in more favourable environments and future changing climates.

In diploid wheat species T. urartu Thum. ex Gandil., T. monococcum, and T. boeoticum Boiss., only awned spikes have been identified to date, but only $T$. sinskajae A. Filat. et Kurk. has awnless spikes (Dorofeev and Korovina, 1979). Among tetraploid wheat species, all except $T$. aethiopicum Jakubz. awnless forms were obtained by hybridisation with T. aestivum. Both awned and awnless forms occur among hexaploid wheat species (Dorofeev and Korovina, 1979). Some accessions of $T$. carthlicum Nevski possess awns and awn-like appendages on the glume; these spikes were named tetraaristatum (four-awned) (Haque et al., 2011) (Fig. 1). In the case of T. aestivum, breeders prefer to produce awnless cultivars. No commercial awnless cultivars of tetraploid wheat species were produced until now, because tetraploid wheat species with awnless spikes are characterised by reduced grain quality.

Spike shattering. Disintegration of the mature spike (disarticulation) allows seed dispersal of wheat species in the field. Two types of spikelet disarticulation have been described for the genus Triticum: barrel (B or Aegilops tauschii Coss. type) and wedge-shaped (W or T. spelta $\mathrm{L}$. type) (Watkins, 1930). The B-type disarticulation is characteristic for hexaploid wheats and results in breakage at the lower side of the junction between the rachis and spikelet base, and the spike disarticulates into individual spikelets with a rachis fragment attached behind each spikelet (Kimber and Feldman, 1987) (Fig. 1). In the case of W-type disarticulation the breakages occurred at the upper side of the junction between the rachis and spikelet base and the spike disarticulates into individual spikelets with rachis attached below each spikelet. W-type disarticulation occurrs in di- and polyploidy wheat species (Kimber and Feldman, 1987) (Fig. 1). Spikes that undergo W- or B-type disarticulation are fragile, while the spikes that do not break easily are non-fragile (tough). Species of $T$. monococcum, $T$. dicoccum and T. timopheevii (Zhuk.) Zhuk. possess a specific type of brittle (fragile) rachis that disarticulates with the slightest mechanical pressure when mature (Dorofeev and Korovina, 1979). The rachis of these species is less brittle compared to wild relatives with a fragile rachis. Transition from natural seed dispersal through shattering to obligate dispersal by humans is a key event in the domestication and evolution of cereals.

Spike shape. Spikes of wheat species can be attributed to one of the three morphological variants of spike shape:

- normal (relatively short square headed parallel-sided spike);

- spelt (pyramidal spikes featuring an elongated rachis and tenacious glumes);

- compact (short, dense spike with fewer spikelets per spike) (Fig. 1) (Dorofeev and Korovina, 1979).

The normal spike shape is widespread among the cultivated wheat species (T. durum, T. aestivum among other) (Dorofeev and Korovina, 1979). Spelt spikes were described for the tetraploid species T. spelta, T. dicoccum, T. dicoccoides (Körn. ex Aschers. et Graebn.) Schweinf. and speltoid mutants of T. aestivum (Dorofeev and Korovina, 1979). The compact spike shape was identified in diploid species $T$. sinskajae and two hexaploid species, $T$. compactum Host and T. sphaerococcum Perciv. (Dorofeev and Korovina, 1979). No accessions with compact spikes have been identified in tetraploid wheat species, while mutants of them (Kosuge et al., 2008) and hybrids between varieties of $T$. dicoccoides and $T$. dicoccum possess less dense spikes (compactoid), in comparison to compact spikes of hexaploid accessions (Malinowski, 1914; Goncharov, 1997).

Spike branching. Normally the wheat spike (branchless spike) is composed of spikelets arranged in two opposite rows along the rachis. In contrast, in branching spikes, spikelets are replaced by lateral branch-like structures resembling small-sized secondary spikes (Fig. 1). This trait is important, because the branch formation produces significantly more grains per spike and thus increases grain yield (Poursarebani et al., 2015). Branching spikes occur in $T$. vavilovii (Thum.) Jakubz. and some varieties of T. turgidum L. Diploid wheat species possess only branchless spikes (Lebedeva and Rigin, 1994).

Number and arrangement of spikelets: supernumerary spikelets. Normal wheat spikes bear one spikelet per rachis node (wild type), while some wheat accessions are characterised by an abnormal phenotype with additional spikelets per rachis node (supernumerary spikelets phenotype) (Pennell and Halloran, 1983) (Fig. 1). Several variants of the supernumerary spikelets phenotype have been identified, such as:

- multirow spike (MRS) with a cluster of spikelets at a rachis node;

- horizontal spikelets (HSs) with three spikelets (triple spikelet) and two spikelets in horizontal positions at a rachis node (Fig. 1). 
Some investigators define the branching spike as a variant of a ramified spike of a supernumerary spikelets phenotype (RS) (Dobrovolskaya et al., 2015).

Wheat accessions with the normal number of spikelets per rachis node prevail on the accessions with supernumerary spikelet spikes. Accessions with supernumerary spikelet spikes have been identified for T. turgidum, T. durum and T. polonicum L. (Klindworth et al., 1990; Lyapunova, p.c.; Goncharov, p.c.). The accessions with supernumerary spikelets represent the promising type for breeding to increase wheat grains yield and to satisfy human demand. It was proposed that wheat grain production must increase at an annual rate of $2 \%$, without any additional land to become available for this crop (Gill et al., 2004).

\section{GENES UNDERLYING SPIKE MORPHOLOGY IN DIF- FERENT WHEAT SPECIES}

Free-threshing vs. non free-threshing grains. Several major genes and loci related to threshability have been previously identified and include the spelt factor gene $(Q)$, tenacious glumes locus ( $\mathrm{Tg}$ ), tenacious glume 2 locus ( $\mathrm{Tg} 2)$ and the soft glume locus ( $\operatorname{sog}$ ) (Kerber and Rowland, 1974; Simonetti et al., 1999; Faris and Gill, 2002; Faris et al., 2003; Sood et al., 2009) (Table 1).

$Q$ gene (synonyms: WAP2, wheat AP2) represents a transcription factor that regulates the threshability in polyploidy wheat species and has a pleiotropic effect on several other important traits, including spike shape, rachis fragility, plant height, and flowering time (Muramatsu, 1963; Kato et al., 1999; Faris and Gill, 2002; Faris et al., 2003; Simons et al., 2006; Zhang et al., 2011). Spelt factor gene was found to be located on the long arm of chromosome $5 \mathrm{~A}$ and has been molecularly cloned for a number of wheat species (Faris and Gill, 2002; Faris et al., 2003; Simons et al., 2006; Sormacheva et al., 2015). Polyploid wheat species has an additional homoeologous loci for $Q$ gene on chromosomes $5 \mathrm{~B}$ and $5 \mathrm{D}$. Analysis of $5 A Q, 5 B q$ and $5 D q$ showed that: (1) $5 A Q$ plays a major role in control of domestication-related traits; (2) $5 B q$ is a pseudogene that does not encode a full-length q protein, but participates in the regulation of expression of $5 A Q$ and $5 D q$; and (3) a combination of the $5 A Q, 5 B q$ and $5 D q$ loci is important for the formation of free-threshing spikes (Simons et al., 2006; Zhang et al., 2011). The $Q^{m}$ gene sequences have been identified for diploids and the spike phenotype was predicted to be regulated by the $S o g$ gene in these species (see below).

$Q$ gene encodes a floral homeotic protein, a member of the AP2 subfamily of plant-specific transcription factors (AP2/ERF family) (Simons et al., 2006). Two different alleles of this gene, $Q$ and $q$ in the A genome, were identified and associated with a particular spike phenotype. The $q$ allele is presented among wild wheat species with non free-threshing grains and fragile speltoid spikes, while $Q$ allele occurs in wild and cultivated species with free-threshing grains and non fragile not speltoid spikes (Simons et al.,
2006; Zhang et al., 2011; Sormacheva et al., 2015). The sequences of $q$ and $Q$ alleles have two main differences: presence of the amino acid substitution in the position 329 (Val/Ile) and the SNP in the binding site of miRNA172 within the exon 10 (T/C). However, all sequences of B and D genomes have Leu in position 329 and 418TTC triplet in the miR172 binding site.

Two mechanisms have been proposed to explain the increased transcription level of $Q$ allele in compare to $q$ in the A genomes. The presence of 329Ile is predicted to increase the formation of $\mathrm{Q}$ homodimers, which could lead to self up-regulation of $5 A Q$ transcription (Simons et al., 2006). The regulation of $Q$ gene expression can occur through miRNA, as was shown for several other members of the AP2 family (Chen, 2004; Simons et al., 2006; Chuck et al., 2007).

Another locus ( $T g$ ) was described for hexaploid wheat species, which is localized on the short arm of the chromosome 2D (Kerber and Rowland, 1974; Rowland and Kerber, 1974; Jantasuriyarat et al., 2004; Sood et al., 2009) (Table 1). It was suggested that $T g$ has a more pronounced effect on threshability than $Q$ gene (Kerber and Rowland, 1974). In tetraploid wheat species, an additional gene that influences the threshability trait $(\mathrm{Tg} 2)$ is located on chromosome 2BS (Simonetti et al., 1999) (Table 1). Thus, the freethreshing trait in tetraploid wheat species is complex and $Q$, $T g 2$ and several minor genes are predicted to be involved in its formation.

T. sinskajae is the only free-threshing diploid wheat species, but no difference among $Q^{m}$ gene sequences from various diploid wheats are known (Simons et al., 2006; Sormacheva et al., 2015). In diploid wheat species the Sog locus is located on the short arm of the chromosome $2 \mathrm{~A}^{\mathrm{m}}$ (Taenzler $e t$ al., 2002) (Table 1). The spike type of T. monococcum is dominant (Goncharov et al., 2007b). The recessive gene sog controls soft glume formation in T. sinskajae and is responsible for the free-threshing character (Amagai et al., 2014). Moreover, free-threshing and soft glume traits display a linkage inheritance together with the specific compact shape in T. sinskajae (Goncharov et al., 2007b). Sood et al., (2009) suggested that $\operatorname{sog}$ and $T g$ are not true orthologues and that they apparently originated differently.

Awned vs. awnless spikes. Watkins and Ellerton (1940) established that the awnless spike phenotype is controlled by three non allelic genes $H d$ (hooded), B1 (tipped 1) and B2 (tipped 2), localised on chromosomes 4AS, 5AL and 6BL, respectively (Rao, 1981; Sears, 1954; Sears, 1966) (Table 1).

In hexaploid wheat species, the dominant gene $B 1$ plays a major role in awnless spike formation (Goncharov, 2012). The only exceptions are several accessions of $T$. aestivum from China and India, in which the dominant genes $B 2$ and $H d$ determine the spikes with specific types of awns (Goncharov, 2012). Goncharov (2012) proposed monogenic control of the awnless phenotype in T. aestivum Pamir 
LIST OF THE GENES UNDERLINING SPIKE MORPHOLOGY IN WHEAT

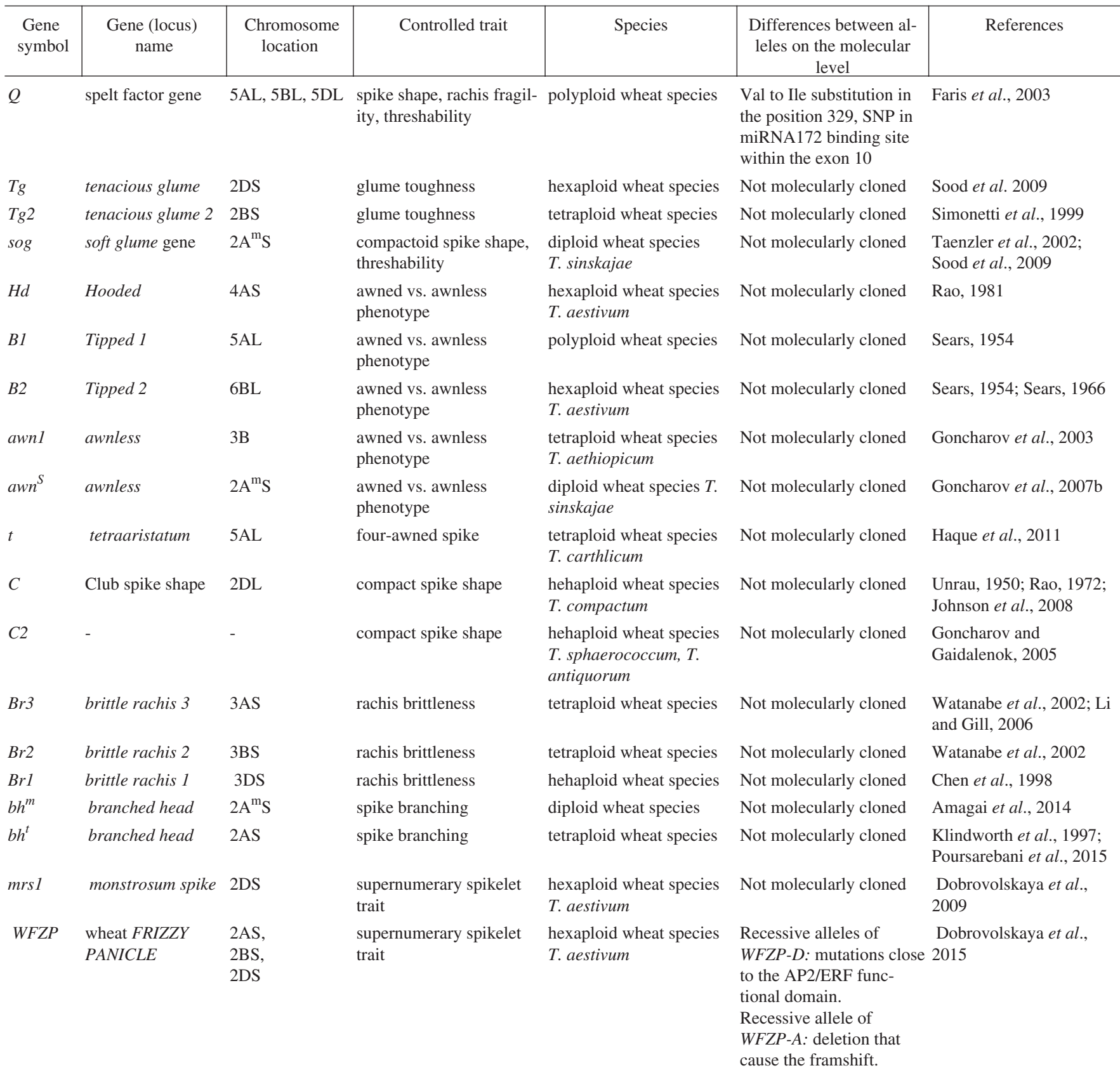

Ppd-D1 Photoperiod-D1 2D

inflorescence architec- hexaploid wheat species

Boden et al., 2015

ture, paired spikelet trait

landraces 'Babilo' and 'Kilyak' by the dominant gene designated as $H d 2$. Recently, locus $T$ controlling awn formation on the glume in $T$. carthlicum (tetraaristatum) has been found to be localised on the long arm of chromosome $5 \mathrm{~A}$ (Haque et al., 2011) (Table 1).

Using genome substitution lines, it was shown that in the only tetraploid species $T$. aethiopicum with awnless forms, this trait is under monogenic control by the recessive gene awnl located on chromosome 3B (Goncharov et al., 2003; Antonyuk et al., 2012). Goncharov et al. (2007) found that the recessive gene $a w n$ was localized on the short arm chromosome $2 \mathrm{~A}$ of $T$. sinskajae.
Genes underlying the presence or absence of awns in wheat are poorly investigated. The localisation of $H d 2$ and awn 1 genes has not been determined. None of the genes involved in awn development or formation of awnless spikes in wheat species have been moleculary cloned so far.

Fragile vs. non-fragile rachis. In addition to the $Q$ gene, three loci $\mathrm{Br} 1, \mathrm{Br} 2$, and $\mathrm{Br} 3$ located on the homoeologous group 3 chromosomes control the rachis character (Chen et al., 1998; Watanabe and Ikebata, 2000; Watanabe et al., 2002; Li and Gill, 2006; Nalam et al., 2006) (Table 1). The recessive alleles of these loci determine the rashis that undergoes one of the disarticulation types described above. 
The $\mathrm{Br}$ locus is localized on the short arm of chromosome $3 \mathrm{D}$ of Tibetan landraces of common wheat and the short arm of chromosomes 3A in T. timopheevii (Chen et al., 1998; Li and Gill, 2006). Recessive alleles of $\mathrm{Br} 2$ and $\mathrm{Br} 3$ located on $3 \mathrm{AS}$ and 3BS determine non-brittle rachis in tetraploids. No alleles of $\mathrm{Brl}, \mathrm{Br} 2$ and $\mathrm{Br} 3$ have been molecularly cloned and no ortologs of these genes are known in cereals.

Spelt vs. normal or compact spike shape. Three main genes/loci are involved in spike shape control in wheat species: $Q, C, C 2$ (Unrau, 1950; Rao, 1972; Goncharov and Gaidalenok, 2005; Simons et al., 2006; Johnson et al., 2008; Zhang et al., 2011; Sormacheva et al., 2015) (Table 1 ). The alleles of $5 A Q$ gene, which determines the normal and spelt spike shape in different wheat species, are described above. Homologous $5 D q$ and $5 B q$ also contribute to the suppression of the spelt phenotype (Zhang et al., 2011).

In the hexaploid wheat species $T$. compactum the compact spike shape is controlled by gene $C$, which is located on the long arm of chromosome 2D (Rao, 1972). Mutation giving rise to the dominant allele $C$ resulted in the origin of club wheat, thus the investigation of this gene is important for the taxonomy of wheat species (Johnson et al., 2008). C2 gene controlling the compact spike characteristic in $T$. sphaerococcum is not allelic to gene $C$ of $T$. compactum (Goncharov and Gaidalenok, 2005). The genome localisation of gene $C 2$ remains unknown. The compactoid spike shape trait in tetraploids is controlled by two nonallelic recessive genes, named scl and sc2 (Goncharov, 1997). The gene $s c 1$ alone is responsible for the semicompactoid spike, while together with gene $s c 2$, leads to compactoid spike formation in tetraploid wheat. Sequences of the genes $C, C 2$, $s c 1$ and sc2 have not been molecularly cloned.

Supernumerary spikelets vs. normal number of spikelets. Some investigators define the branched spikes in which the additional spikelets number increases due to growth of the secondary spike rachis as a variant of supernumerary spikelets spikes (SS). The branched spike phenotype is common in tetraploid species T. turgidum and a single major locus $b h^{t}$ (branched head) located on the short arm of the chromosome $2 \mathrm{~A}$ is predicted to control this trait (Haque et al., 2012) (Table 1). Recently it was shown that the branched phenotype in $T$. sinskajae is under control of a recessive allele at a single locus and that this locus $b h^{m}$ is located on the $2 \mathrm{~A}^{\mathrm{m}} \mathrm{S}$ (Amagai et al., 2014) (Table 1).

In wheat species, the supernumerary spikelet trait is recessive. WFZP (wheat FRIZZY PANICLE) and $m r s 1$ (monstrosum spike) are the loci that control the formation of spikes with supernumerary spikelets in T. aestivum species (Dobrovolskaya et al., 2009; Dobrovolskaya et al., 2015) (Table 1). The mrsl gene mapped on chromosome 2DS is a predicted ortholog of $b h$ loci. WFZP-A, WFZP-B and $W F Z P-D$ are located on homoeologous group 2 chromosomes (Dobrovolskaya et al., 2015). WFZP gene encodes an APETALA2/ERF transcription factor that probably inhibits SS phenotype formation. qRT-PCR and comparative se- quence analysis showed that WFZP-D is the main contributor to the SS phenotype in bread wheat, while $W F Z P-B$ is non functional and possess the miniature inverted-repeat TEs inserted within the promoter region (Dobrovolskaya et al., 2015). For $W F Z P-D$, two recessive alleles are associated with SS phenotypes: $w f z p-D .1$ with the G-A substitution within the GCC-box binding site of the AP2/ERF functional domain and $w f z p-D .2$ with $\mathrm{C}-\mathrm{T}$ substitution in AP2/ERF. The recessive allele of the WFZP-A (wfzp-A.1) possesses a deletion $14 \mathrm{bp}$ in length close to the functional AP2/ERF domain, which causes the frameshift (Dobrovolskaya et al., 2015). Different combinations of the alleles described above cause the differences in the phenotypic manifestations of the SS trait in T. aestivum.

Recently, in a comprehensive study, the influence of Ppd-Dl gene on inflorescence architecture and paired spikelet development in hexaploid wheat species was described (Boden et al., 2015).

\section{ORTHOLOGS OF SPIKE MORPHOLOGY GENES IN TRITICEAE TRIBE}

A number of genes influence spike morphology in other species of subtribe Frumentaceae, namely in barley and rye. Only eight genes from barley, including INT-C, Nud, vrs l, Vrs4, Btr1, Btr2, Bkn3 and HvAP2, have been molecularly cloned (Takahashi and Hayashi, 1964; Muller et al., 1995; Franckowiack and Konishi, 1997; Komatsuda and Mano, 2002; Santi et al., 2003; Komatsuda et al., 2007; Taketa et al., 2008; Ramsay et al., 2011; Houston et al., 2013; Koppolu et al., 2013; Taketa et al., 2013; Pourkheirandish et al., 2015; Yu et al., 2016). No genes related to spike morphology in rye have been cloned so far.

The sequences of eight genes involved in the regulation of grass inflorescence architecture in barley have been used for BLAST search against the NCBI databases. Homological sequences have been found in wheat, Brachypodium distachyon (L.) P. Beauv., rice, sorghum, and maize for four of them: Vrs1, Vrs4, Nud, and HvAP2. Homological sequences of two genes (Btr1 and Btr2) have been found in wheat only, while genes INT-C and Bkn3 showed no homological sequences in the cereal genomes. All isolated sequences were aligned and used for the phylogenetic analysis. Multiple DNA alignments were performed by ClustalW (Thompson et al., 1994) with improvements by the MUSCLE algorithm in UGENE Results software (Okonechnikov et al., 2012). Phylogenetic analyses were performed using the neighbour-joining (NJ) method in MEGA7 software (Tamura et al., 2011). Statistical support for the NJ tree was evaluated by bootstrapping (1000 replications) (Felsenstein, 1985).

Vrs 1 -like genes. Vrs 1 is a member of the HD-ZIP class of transcription factors, and encodes a transcription factor that includes a homeodomain with a closely linked leucine zipper motif. HD-Zip-encoding genes have been isolated from a wide variety of plants and grouped into four families 


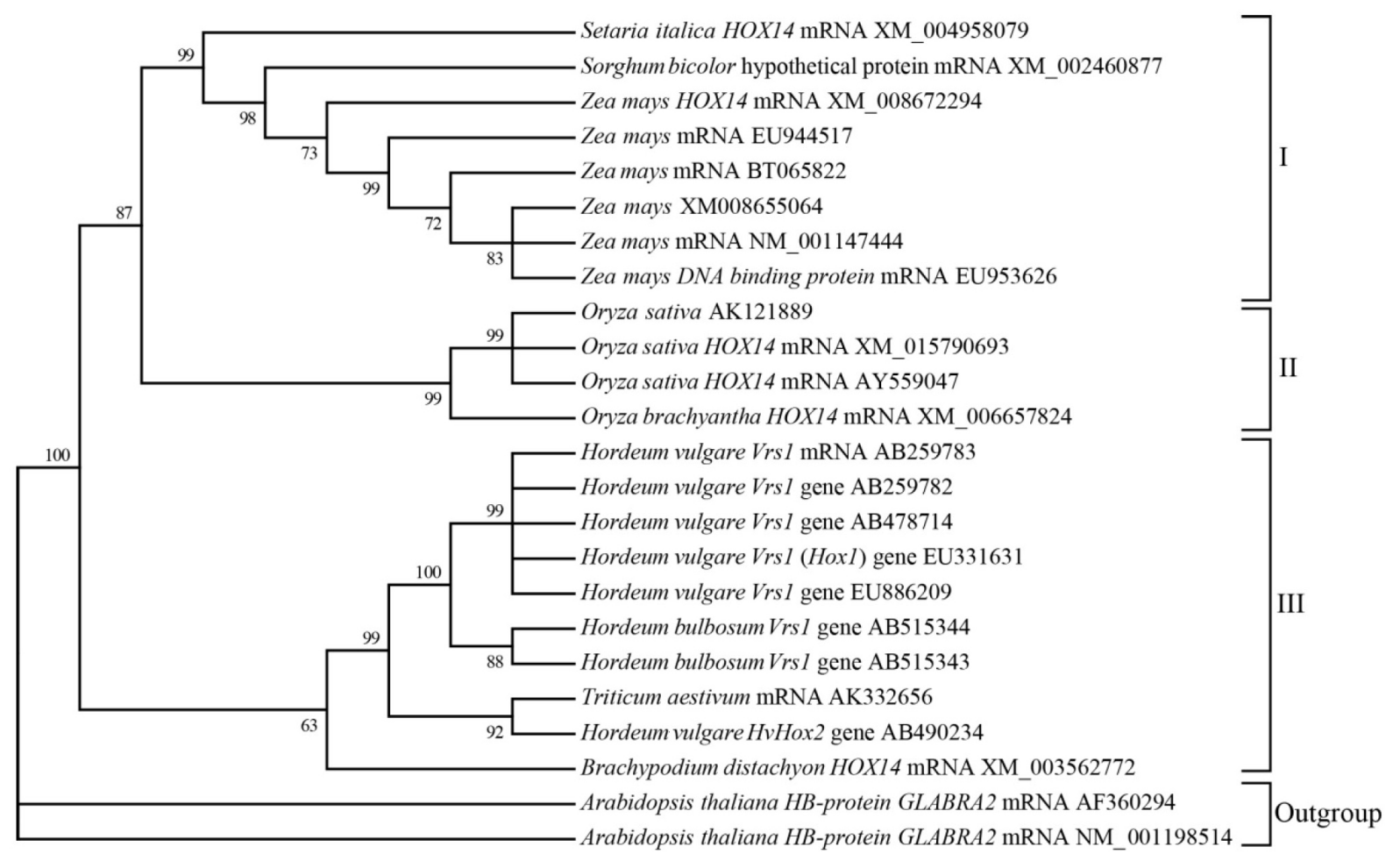

Fig. 2. Neighbour-joining (NJ) phylogenetic tree based on the coding region of Vrsl genes from various cereal species and their homologs identified from GenBank. Statistical support was evaluated by bootstrapping (1000 replications); nodes with bootstrap values over $50 \%$ are indicated. Sequences from Arabidopsis thaliana that were homological to the Vrs 1 gene were used as outgroups.

(I-IV) (Sessa et al. 1994, Ariel et al., 2007). The barley VRS1 gene belongs to family I (Sakuma et al., 2010). Expression of $V r s 1$ is localised in the lateral-spikelet primordia of immature spikes, suggesting that the VRS1 protein suppresses development of the lateral rows. Homological sequences to the VRS1 sequences were selected by BLAST search in the NCBI databases against wheat, B. distachyon, rice, sorghum, and maize. The resulting phylogenetic tree is shown in Fig. 2. Three branches, in addition to the outgroup, are present in the phylogenetic tree. The first branch includes the homeobox-leucine zipper genes HOX14-like, mainly predicted, from three specimens: Zea mays L., Sorghum bicolor (L.) Moench, and Setaria italic (L.) P. Beauv. The second branch is monophyletic and consists of the genes that encode homeobox-leucine zipper protein HOX14 in rice (Oryza sativa L.). Finally, the third branch mainly is formed by Vrsl sequences of barley (Hordeum vulgare L. and Hordeum bulbosum L.), but two predicted VrsI sequences of T. aestivum and Brachipodium distachyon are also placed in this branch.

Vrs4 (RAMOSA2). Vrs4 is a barley ortholog of the maize inflorescence architecture gene RAMOSA2 (RA2) (Koppolu et al., 2013). This group of transcriptional factors plays a significant role in the control of inflorescence development in grasses. Therefore, these transcriptional factors are present in all cereals. The evolutionary relationships of the $R A 2$ genes are shown in Fig. 3. The $R 2$ tree contains the same three branches as the previous tree: Zea mays, Sorghum bicolor, and Setaria italic (branch I); Oryza sativa (branch II); and two Hordeum species, two Triticum species, and Brachipodium distachyon (branch III).
$Q$ gene (APETALA2-like genes). The APETALA2-like genes $(A P 2)$ form a large multi-gene family of transcription factors, including $Q$ gene described for wheat. The APETALA2-like proteins play an important role during the plant life cycle, being key regulators of many developmental processes. Phylogenetic analysis showed that the phylogenetic relationships of the APETALA2-like genes from cereals are similar to both the Vrsl-like and RA2 genes described above (Fig. 4). The same three branches are present in the APETALA2-like tree: Zea mays, Sorghum bicolor, and Setaria italic (branch II); O. sativa (branch III); and $H$. vulgare, Triticum species, Ae. tauscii, and $B$. distachyon (branch I). Additionally, two other branches are present in the tree. Both branch V and branch IV include sequences of the AP2-like ethylene-responsive transcription factor TOE3 from Z. mays and O. brachyantha A. Chev. \& Roehr. plus $B$. distachyon, correspondingly.

Nud (WIN1-like genes). The gene for naked caryopsis, nud, has been described for barley only. No other crops in the tribe Triticeae show such a differentiation in grain type (Taketa et al., 2004). Our phylogenetic analysis showed that the nud gene from Hordeum vulgare is the most closely related to the ethylene-responsive transcription factor WINI (Fig. 5). Three of four branches in the tree (I, II, III) are the same as in the other first trees. The branch IV includes WIN1 sequences from three different species. We can suggest that this group of genes may be different from the transcription factor WIN1.

Finally, two genes, Btrl and Btr2, which had been described as transcriptional factors for the Hordeum vulgare 

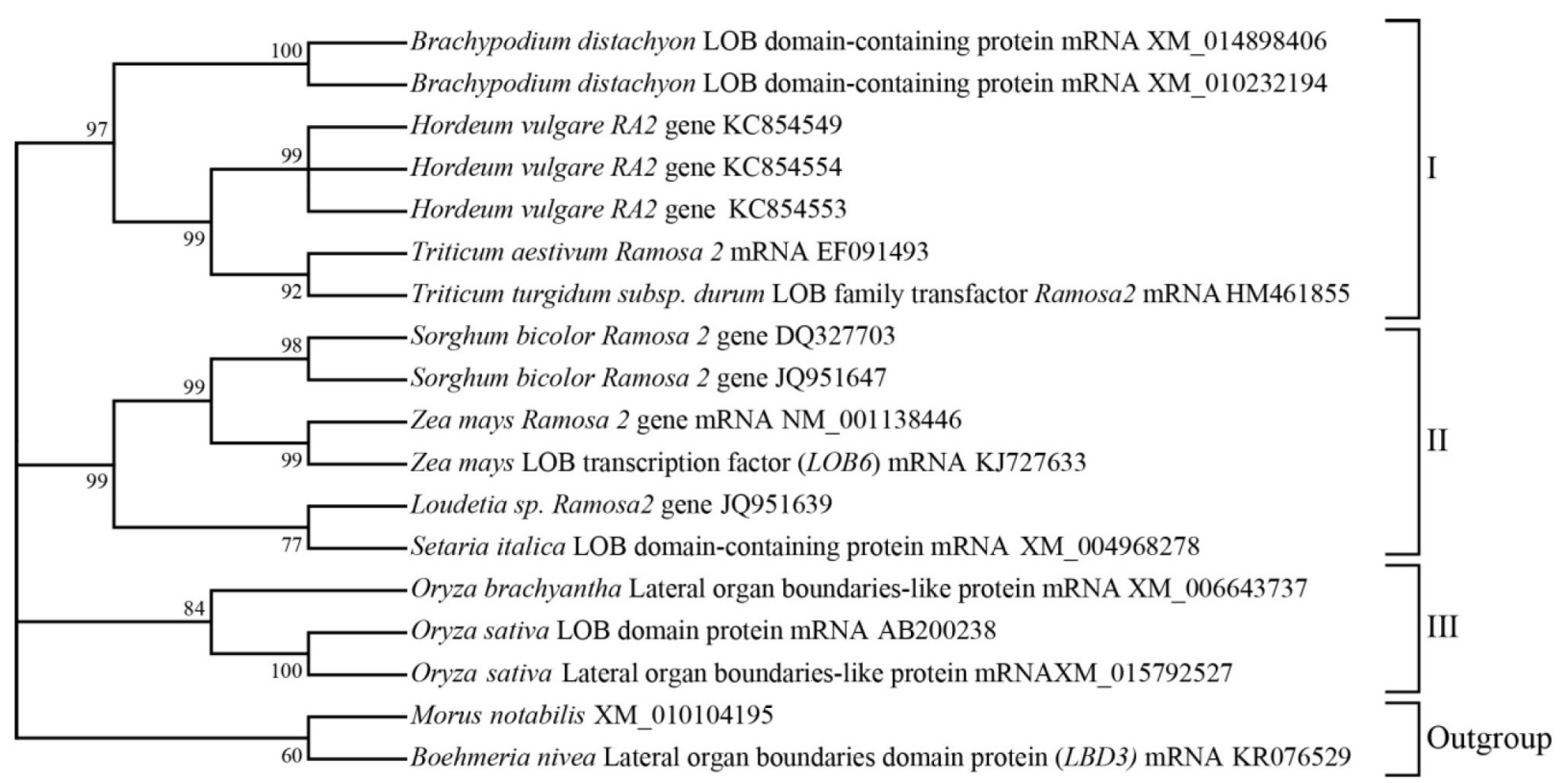

Fig. 3. Neighbour-joining (NJ) phylogenetic tree based on the coding region of Vrs4 genes from various cereal species and their homologues identified from GenBank. Statistical support was evaluated by bootstrapping (1000 replications); nodes with bootstrap values over $50 \%$ are indicated. Sequences from Morus notabilis and Boehmeria nivea that were homological to the Vrs4 gene were used as outgroups.

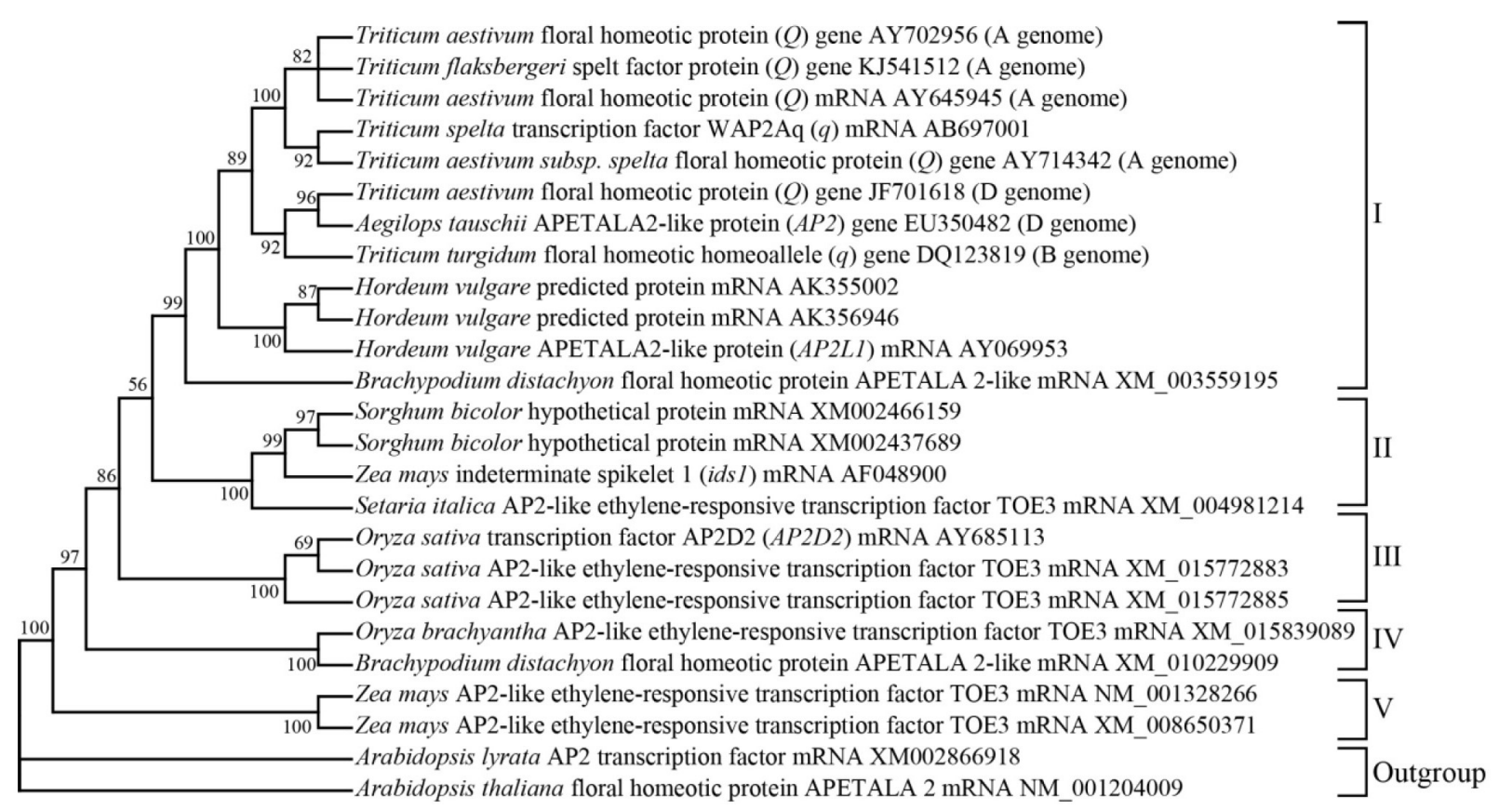

Fig. 4. Neighbour-joining (NJ) phylogenetic tree based on the coding region of $Q$ genes from various cereal species and their homologues identified from GenBank. Statistical support was evaluated by bootstrapping (1000 replications); nodes with bootstrap values over $50 \%$ are indicated. APETAL2 gene sequences from Arabidopsis spp. were used as outgroups.

genome (Komatsuda and Mano, 2002), were not found in the tested cereal genomes, except for two Triticum species in which the homologous nucleotide sequences to both Btrl and Btr2 have been found (GenBank Ac. N. HG670306 and KR813812).

\section{CONCLUSIONS}

Plant genomes can be modified by several techniques. In the present review we described genes commonly used in standard breeding practice and several genes that control the wheat trait and could increase the biodiversity of commercial cultivars of modern wheat. During domestication and following cultivation, some genes underlying agronomically important traits were excluded from traditional breeding. A common drawback of the knowledge in the field of spike morphology genes in wheat is insufficient from the viewpoint of molecular biology and accurate description of the cultivar's phenotypes. Comprehensive studies, which combine the analysis of wheat genes and orthologous genes of related wheat species, such as barley and rye, are required 

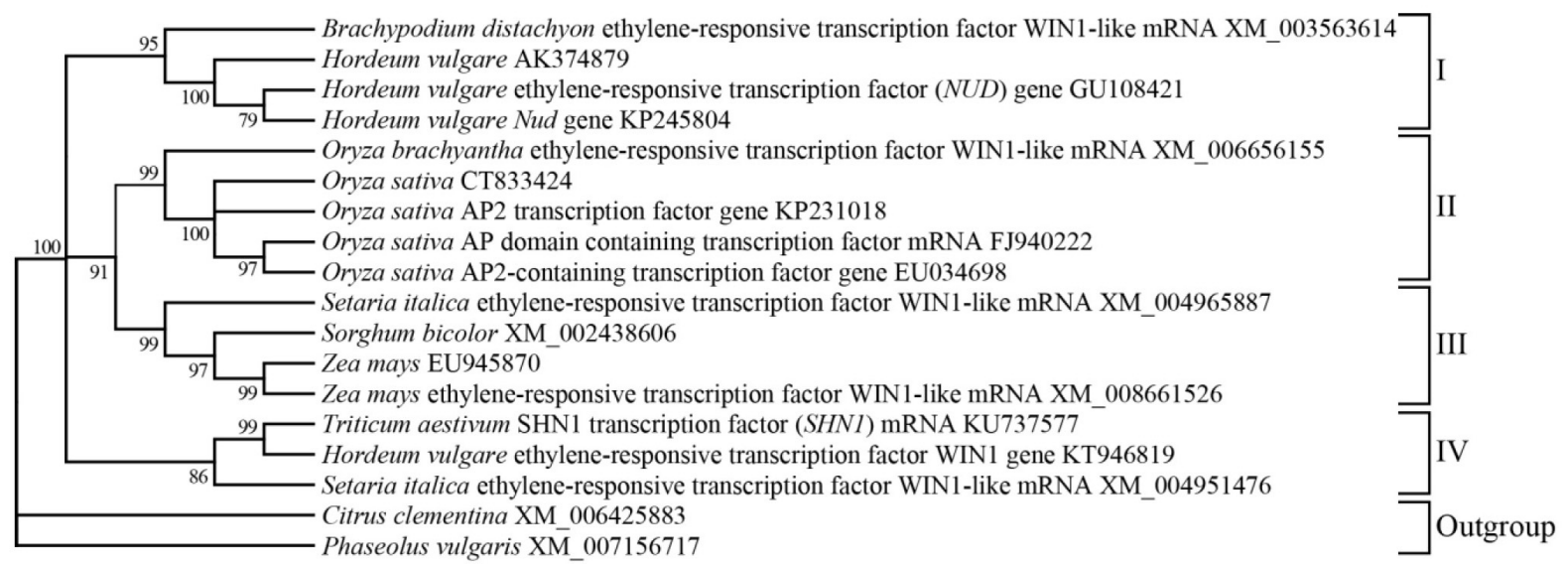

Fig. 5. Neighbour-joining (NJ) phylogenetic tree based on the coding region of $\mathrm{Nud}$ genes from various cereal species and their homologues identified from GenBank. Statistical support was evaluated by bootstrapping (1000 replications); nodes with bootstrap values over $50 \%$ are indicated. Sequences from Citrus elemtina and Phaseolus vulgaris that were homological to the Nud gene were used as outgroups.

to eliminate this drawback. At present, it is clear that only the combination of comparative genetic and molecular biological studies will provide the reliable modern tools that could change the architectonic structure of cultivated wheat.

\section{ACKNOWLEDGMENTS}

The work was supported by the Russian Science Foundation (grant number: 16-16-10021).

\section{REFERENCES}

Amagai, Y., Martinek, P., Watanabe, N., Kuboyama, T. (2014). Microsatellite mapping of genes for branched spike and soft glumes in Triticum monococcum L. Genet. Resour. Crop Ev., 61 (2), 465-471.

Anonymous (2015). FAOSTAT.FAO, Rome, Italy. Available at: http://faostat.fao.org (accessed 15 August 2016).

Antonyuk, M. Z., Prokopyk, D. O., Martynenko, V. S., Ternovska, T. K. (2012). Identification of the genes promoting awnedness in the Triticum aestivum/Aegilops umbellulataintrogressive line. Cytol. Genet., 46 (3), 136-143.

Ariel, F. D., Manavella, P. A., Dezar, C. A., Chan, R. L. (2007). The true story of the HD-Zip family. Trends Plant Sci., 12 (9), 419-426.

Boden, S. A., Cavanagh, C., Cullis, B. R., Ramm, K., Greenwood, J., Finnegan, E. J., Trevaskis, B., Swain, S. M. (2015). Ppd-1 is a key regulator of inflorescence architecture and paired spikelet development in wheat. Nat. Plants, 1, doi: 10.1038/nplants.2014.16

Chen, Q. F., Yen, C., Yang, J. L. (1998). Chromosome location of the gene for the hulled character in the Tibetan weedrace of common wheat. Genet. Resour. Crop Ev., 45, 407-410.

Chen, X. (2004). A microRNA as a translational repressor of APETALA2 in Arabidopsis flower development. Science, 303, 2022-2025.

Chuck, G., Meeley, R., Irish, E., Sakai, H., Hake, S. (2007). The maize tasselseed 4 microRNA controls sex determination and meristem cell fate by targeting Tasselseed6/indeterminate spikelet1. Nat. Genet., 39 (12), $1517-1521$.

Dobrovolskaya, O., Martinek, P., Voylokov, A. V., Korzun, V., Roder, M. S., Borner, A. (2009). Microsatellite mapping of genes that determine supernumerary spikelets in wheat (T. aestivum) and rye (S. cereale). Theor. Appl. Genet., 119 (5), 867-874.

Dobrovolskaya, O., Pont, C., Sibout, R., Martinek, P., Badaeva, E., Murat, F., Chosson, A., Watanabe, N., Prat, E., Gautier, N., Gautier, V., Poncet, C., Orlov. Y. L., Krasnikov, A. A., Berges, H., Salina, E., Laikova, L.,
Salse, J. (2015). FRIZZY PANICLE drives supernumerary spikelets in bread wheat. Plant Physiol., 167 (1), 189-99.

Doebley, J. F., Gaut, B. S., Smith, B. D. (2006). The molecular genetics of crop domestication. Cell, 127 (7), 1309-1321.

Dorofeev, V.F., Korovina, O. N. (1979). Wheat. Flora of Cultivated Plants, Vol. 1. [Дорофеев В. Ф., Коровина О. Н. Культурная флора СССР. T. 1. Пиеница.] Kolos, Leningrad. 347 pp. (in Russian).

Faris, J. D., Gill, B. S. (2002). Genomic targeting and high-resolution mapping of the domestication gene. Genome, 45, 706-718.

Faris, J. D., Fellers, J. P., Brooks, S. A., Gill, B. S. (2003). A bacterial artificial chromosome contig spanning the major domestication locus $\mathrm{Q}$ in wheat and identification of a candidate gene. Genetics, 164 (1), 311-321.

Franckowiack, J. D., Konishi, T. (1997). Naked caryopsis. Barley Genetics Newsletter, 26, 51-52.

Gepts, P. (2004). Crop domestication as a long-term Selection Experiment. Plant Breeding, 24 (2), 1-44.

Gill, B. S., Appels, R., Botha-Oberholster, A. M., Buell, C. R., Bennetzen, J. L., Chalhoub, B., Chumley, F., Dvorak, J., Iwanaga, M., Keller, B., Li, W., McCombie, W. R., Ogihara, Y., Quetier, F., Sasaki, T. (2004). A workshop report on wheat genome sequencing: International genome research on wheat consortium. Genetics, 168 (2), 1087-1096.

Glémin, S., Bataillon, T. (2009). A comparative view of the evolution of grasses under domestication: Tansley review. New Phytol., 183 (2), 273-290.

Goncharov, N. P. (1997). Comparative genetic study of tetraploid forms of common wheat without D genome. Russ. J. Genet., 33, 549-552.

Goncharov, N. P., Mitina, R. L., Anfilova, N. A. (2003). Inheritance of awnlessness in tetraploid wheat species. Russ. J. Genet., 39 (4), 463-466.

Goncharov, N. P., Gaidalenok, R. F. (2005). Localization of genes controlling spherical grain and compact ear in Triticum antiquorum Heer ex Udacz. Russ. J. Genet., 41 (11), 1262-1267.

Goncharov, N. P., Bannikova, S. V., Kawahara, T. (2007a). Wheat artificial amphiploids involving the Triticum timopheevii genome: Their studies, preservation and reproduction. Genet. Resour. Crop Ev., 54 (7), 1507-1516.

Goncharov, N. P., Kondratenko, E. Y., Bannikova, S. V, Konovalov, A. A., Golovnina, K. A. (2007b). Comparative genetic analysis of diploid naked wheat Triticum sinskajae and the progenitor T. monococcum accession. Russ. J. Genet., 43 (11), 1248-1256.

Goncharov, N. P. (2011). Genus Triticum L. taxonomy: The present and the future. Plant Syst. Evol., 295 (1), 1-11. 
Goncharov, N. P. (2012) Comparative Genetics of Wheats and Their Related Species. [Гончаров Н. П. Сравнительная генетика пшении и их сородичей.] GEO, Novosibirsk. 523 pp. (in Russian).

Gross, B. L., Olsen, K. M. (2010). Genetic perspectives on crop domestication. Trends Plant Sci., 15 (9), 529-537.

Gu, X. Y., Kianian, S. F., Foley, M. E. (2004). Multiple loci and epistases control genetic variation for seed dormancy in weedy rice (Oryza sativa). Genetics, 166 (3), 1503-1516.

Hammer, K. (1984). Das Domestikationssyndrom. Die Kulturpflanze, 32 (1), $11-34$.

Haque, M. A., Takayama, A., Watanabe, N., Kuboyama, T. (2011) Cytological and genetic mapping of the gene for four-awned phenotype in Triticum carthlicum Nevski. Genet. Resour. Crop Evol., 58 (7), 1087-1093.

Houston, K., McKim, S. M., Comadran, J., Bonar, N., Druka, I., Uzrek, N., Cirillo, E., Guzy-Wrobelska, J., Collins, N. C., Halpin, C., Hansson, M., Dockter, C., Druka, A., Waugh, R. (2013). Variation in the interaction between alleles of HvAPETALA2 and microRNA172 determines the density of grains on the barley inflorescence. P. Natl. Acad. Sci. USA, 110 (41), $16675-16680$.

Jantasuriyarat, C., Vales, M. I., Watson, C. J. W., Riera-Lizarazu, O. (2004). Identification and mapping of genetic loci affecting the free-threshing habit and spike compactness in wheat (Triticum aestivum L.). Theor. Appl. Genet., 108 (2), 261-273.

Johnson, E. B., Nalam, V. J., Zemetra, R. S., Riera-Lizarazu, O. (2008). Mapping the compactum locus in wheat (Triticum aestivum L.) and its relationship to other spike morphology genes of the Triticeae. Euphytica, 163 (2), 193-201.

Kato, K., Miura, H., Sawada, S. (1999). QTL mapping of genes controlling ear emergence time and plant height on chromosome 5A of wheat. Theor. Appl. Genet., 98, 472-477.

Kerber, E. R., Rowland, G. G. (1974). Origin of the free threshing character in hexaploid wheat. Can. J. Genet. Cytol., 16 (1), 145-154.

Kimber, G., Feldman, M. (1987). Wild Wheat: An Introduction. College of Agriculture, University of Missouri-Columbia, Columbia, Mo. 146 pp.

Kimber, G., Sears, E. R. (1987). Evolution in the genus Triticum and the origin of cultivated wheat. In: Heyne, E. G. (Ed.). Wheat and Wheat Improvement. 2nd edn. American Society of Agronomy, Madison, WI, pp. $154-164$

Klindworth, D. L., Williams, N. D., Joppa, L. R. (1990). Chromosomal location of genes for supernumerary spikelet in tetraploid wheat. Genome, $\mathbf{3 3}$ (4), 515-520

Klindworth, D. L., Klindworth, M. M., Williams, N. D. (1997). Telosomic mapping of four genetic markers in durum wheat. J. Hered., 88 (3), 229-232.

Komatsuda, T., Mano, Y. (2002). Molecular mapping of the intermedium spike-c (int-c) and non-brittle rachis 1 (btrl) loci in barley (Hordeum vulgare L.). Theor. Appl. Genet., 105 (1), 85-90.

Komatsuda, T., Pourkheirandish, M., He, C., Azhaguvel, P., Kanamori, H., Perovic, D., Stein, N., Graner, A., Wicker, T., Tagiri, A., Lundqvist, U., Fujimura, T., Matsuoka, M., Matsumoto, T., Yano, M. (2007). Six-rowed barley originated from a mutation in a homeodomain-leucine zipper I-class homeobox gene. Proc. Natl. Acad. Sci. USA, 104 (4), 1424-1429.

Koppolu, R., Anwar, N., Sakuma, S., Tagiri, A., Lundqvist, U., Pourkheirandish, M., Rutten, T., Seiler, C., Himmelbach, A., Ariyadasa, R., Youssef, H. M., Stein, N., Sreenivasulu, N., Komatsuda, T., Schnurbusch, T. (2013). Six-rowed spike4 (Vrs4) controls spikelet determinacy and row-type in barley. Proc. Natl. Acad. Sci. USA, 110 (32), 13198-203.

Kosuge, K., Watanabe, N., Kuboyama, T., Melnik, V. M., Yanchenko, V. I., Rosova, M. A., Goncharov, N. P. (2008). Cytological and microsatellite mapping of mutant genes for spherical grain and compact spikes in durum wheat. Euphytica, 159 (3), 289-296.

Lebedeva, T. V., Rigin, B. V. (1994). Inheritance of some morphological traits, growth habit and powdery mildew resistance in cultivated einkorn Triticum monococcum L. Russ. J. Genet., 30, 1599-1604.
Lenser, T., Theißen, G. (2013). Molecular mechanisms involved in convergent crop domestication. Trends in Plant Sci., 18 (12), 704-714.

Lev-Yadun, S., Gopher, A., Abbo, S. (2000). The cradle of agriculture. Science, 288, 1602-1603.

Li, W., Gill, B. S. (2006). Multiple genetic pathways for seed shattering in the grasses. Funct. Integr. Genom., 6 (4), 300-309.

MacKey, J. (1954). Neutron and X-ray experiments in wheat and a revision of the speltoid problem. Hereditas, 40, 65-180.

Malinowski, E. (1914). Les hybrides du froment. Bull. del'Acad. Sci. Cracovie, Ser. B Sci. Naturalis, 3, 410-450.

Maydup, M. L., Antonietta, M., Guiamet, J. J., Graciano, C., Lopez, J. R., Tambussi, E. A. (2010). The contribution of ear photosynthesis to grain filling in bread wheat (Triticum aestivum L.). Field Crop. Res., 119 (1), $48-58$.

Muller, K. J., Romano, N., Gerstner, O., Garcia-Maroto, F., Pozzi, C., Salamini, F., Rohde, W. (1995). The barley Hooded mutation caused by a duplication in homeobox gene intron. Nature, 374, 727-730.

Muramatsu, M. (1963). Dosage effect of the spelta gene $q$ of hexaploid wheat. Genetics, 48, 469-482.

Nalam, V. J., Vales, M. I., Watson, C. J. W., Kianian, S. F., Riera-Lizarazu, O. (2006). Map-based analysis of genes affecting the brittle rachis character in tetraploid wheat (Triticum turgidum L.). Theor. Appl. Genet., 112 (2), $373-381$.

Pennell, A. L., Halloran, G. M. (1983). Inheritance of supernumerary spikelets in wheat. Euphytica, 32 (3), 767-776.

Pourkheirandish, M., Wicker, T., Stein, N., Fujimura, T., Komatsuda, T. (2007). Analysis of the barley chromosome 2 region containing the six-rowed spike gene vrs 1 reveals a breakdown of rice-barley micro collinearity by a transposition. Theor. Appl. Genet., 114 (8), 1357-1365.

Poursarebani, N., Seidensticker, T., Koppolu, R., Trautewig, C., Gawroński, P., Bini, F., Govind, G., Rutten, T., Sakuma, S., Tagiri, A., Wolde, G. M., Youssef, H. M., Battal, A., Ciannamea, S., Fusca, T., Nussbaumer, T., Pozzi, C., Borner, A., Lundqvist, U., Komatsuda, T., Salvi, S., Tuberosa, R., Uauy, C., Sreenivasulu, N., Rossini, L., Schnurbusch, T. (2015). The genetic basis of composite spike form in barley and "miracle-wheat." $G e$ netics, 201 (1), 155-165.

Ramsay, L., Comadran, J., Druka, A., Marshall, D. F., Thomas, W. T. B., Macaulay, M., MacKenzie, K., Simpson, C., Fuller, J., Bonar, N., Hayes, P. M., Lundqvist, U., Franckowiak, J. D., Close, T. J., Muehlbauer, G. J., Waugh, R. (2011). INTERMEDIUM-C, a modifier of lateral spikelet fertility in barley, is an ortholog of the maize domestication gene TEOSINTE BRANCHED 1. Nature Genet., 43 (2), 169-172.

Rao, M. V.P. (1972). Mapping of the compactum gene $C$ on chromosome 2D of wheat. Wheat. Inf. Serv., 35, 9.

Rao, M. V. P. (1981). Telocentric mapping of the awn inhibitor gene Hd on chromosome 4B of common wheat. Cereal Res. Comm., 9, 335-337.

Rebetzke, G. J., Bonnett, D. G., Reynolds, M. P. (2016). Awns reduce grain number to increase grain size and harvestable yield in irrigated and rainfed spring wheat. J. Exp. Bot., 67(9), 2573-2586.

Reynolds, M., Tuberosa, R. (2008). Translational research impacting on crop productivity in drought-prone environments. Curr. Opin. Plant Biol., 11 (2), 171-179.

Rowland, G. G., Kerber, E. R. (1974). Telocentric mapping in hexaploid wheat of genes for leaf resistance and other characters derived from Aegilops squarrose. Can. J. Genet. Cytol., 16, 137-144.

Sakuma, S., Pourkheirandish, M., Matsumoto, T., Koba, T., Komatsuda, T. (2010). Duplication of a well-conserved homeodomain-leucine zipper transcription factor gene in barley generates a copy with more specific functions. Funct. Integr. Genom., 10 (1), 123-133.

Santi, L., Wang, Y., Stile, M. R., Berendzen, K., Wanke, D., Roig, C., Pozzi, C., Muller, K., Muller, J., Rohde, W., Salamini, F. (2003). The GA octodinucleotide repeat binding factor BBR participates in the 
transcriptional regulation of the homeobox gene Bkn3. Plant J., 34 (6), $813-826$.

Sears, E. R. (1947). The sphaerococcum gene in wheat. Genetics, 32, $102-103$.

Sears, E. R. (1954). The aneuplolds of common wheat. Missouri Agr. Exp. Sta. Res. Bull., 572, 1-58.

Sears, E. R. (1966). Chromosome mapping with the aid of telocentrics. Proc. 2nd International Wheat Geneties Symposium, Hereditas Suppl., 2, $370-381$

Sessa, G., Carabelli, M., Ruberti, I., Lucchetti, S., Baima, S., Morelli, G. (1994). Identification of distinct families of HD-Zip proteins in Arabidopsis thaliana. In: G. Coruzzi, P. Puigdomčnech (eds.). Plant Molecular Biology: Molecular Genetic Analysis of Plant Development and Metabolism. Springer, Berlin, Heidelberg, pp. 411-426.

Simonetti, M. C., Bellomo, M. P., Laghetti, G., Perrino, P., Simeone, R., Blanco, A. (1999). Quantitative trait loci influencing free-threshing habit in tetraploid wheats. Genet. Resour. Crop Ev., 46 (3), 267-271.

Simons, K. J., Fellers, J. P., Trick, H. N., Zhang, Z., Tai, Y. S., Gill, B. S., Faris, J. D. (2006). Molecular characterization of the major wheat domestication gene $Q$. Genetics, 172 (1), 547-555.

Sood, S., Kuraparthy, V., Bai, G., Dhaliwal, H. S., Gill, B. S. (2007) Molecular mapping of soft glume ( $\mathrm{Sog}$ ) gene in diploid wheat. In: Abstracts of the Plant \& Animal Genomes XV Conference, 13-17 January 2007, San Diego, CA, p. 282.

Sood, S., Kuraparthy, V., Bai, G., Gill, B. S. (2009). The major threshability genes soft glume ( $\mathrm{sog}$ ) and tenacious glume $(\mathrm{Tg})$, of diploid and polyploid wheat, trace their origin to independent mutations at non-orthologous loci. Theor. Appl. Genet., 119 (2), 341-351.

Sormacheva, I., Golovnina, K., Vavilova, V., Kosuge, K., Watanabe, N., Blinov, A., Goncharov, N. P. (2015). $Q$ gene variability in wheat species with different spike morphology. Genet. Resour. Crop Ev., 62 (6), $837-852$

Sweeney, M. T. (2006). Caught red-handed: Rc encodes a basic helix-loop-helix protein conditioning red pericarp in rice. Plant Cell, 18 (2), 283-294.

Received 19 August 2016
Tadesse, W., Amri, A., Ogbonnaya, F. C., Sanchez-Garcia, M., Sohail, Q., Baum, M. (2015). Wheat. In: Genetic and Genomic Resources for Grain Cereals Improvement. Academic Press, Oxford, pp. 81-124.

Taenzler, B., Esposti, R. F., Vaccino, P., Brandolini, A., Effgen, S., Heun, M., Schafer-Pregl, R., Borghi, B., Salamini, F. (2002). Molecular linkage map of Einkorn wheat: Mapping of storage-protein and soft-glume genes and bread-making quality QTLs. Genet. Res., 80 (2), 131-143.

Takahashi, R., Hayashi, J. (1964). Linkage study of two complementary genes for brittle rachis in barley. Berichte des Ohara Instituts, 12, 99-105.

Taketa, S., Amano, S., Tsujino, Y., Sato, T., Saisho, D., Kakeda, K., Nomura, M., Suzuki, T., Matsumoto, T., Sato, K., Kanamori, H., Kawasaki, S., Takeda, K. (2008). Barley grain with adhering hulls is controlled by an ERF family transcription factor gene regulating a lipid biosynthesis pathway. Proc. Natl. Acad. Sci. USA, 105 (10), 4062-4067.

Taketa, S., Kikuchi, S., Awayama, T., Yamamoto, S., Ichii, M., Kawasaki, S. (2004). Monophyletic origin of naked barley inferred from molecular analyses of a marker closely linked to the naked caryopsis gene (nud). Theor. Appl. Gen., 108, 1236-1242.

Taketa, S., Yuo, T., Yamashita, Y., Ozeki, M., Haruyama, N., Hidekazu, M., Kanamori, H., Matsumoto, T., Kakeda, K., Sato, K. (2013). Molecular mechanisms for covered vs. naked caryopsis in barley. In: Advance in Barley Sciences, Proceedings of 11th International Barley Genetics Symposium, Zhejiang, China, pp. 453-460.

Unrau, J. (1950). The use of monosomes and nullisomes in cytogenetic studies of common wheat. Sci. Agri., 30, 66-89.

Watanabe, N., Ikebata, N. (2000). The effects of homoeologous group 3 chromosomes on grain colour dependent seed dormancy and brittle rachis in tetraploid wheat. Euphytica, 115 (3), 215-220.

Watanabe, N., Sugiyama, K., Yamagishi, Y., Sakata, Y. (2002). Comparative telosomic mapping of homoeologous genes for brittle rachis in tetraploid and hexaploid wheats. Hereditas, 137, 180-185.

Watkins, A. E. (1930). Wheat species. J. Gen., 23, 173.

Yu, S., Long, H., Deng, G., Pan, Z., Liang, J., Zeng, X., Tang, Y., Tashi, N., $\mathrm{Yu}$, M. (2016). A single nucleotide polymorphism of nud converts the caryopsis type of barley (Hordeum vulgare L.). Plant Mol. Biol. Rep., 34 (1), 242-248.

Zhang, Z., Belcram, H., Magdelenat, G., Couloux, A., Samain, S., Gill, S., Rasmussena, J. B., Barbed, V., Faris, J. D., Huneau, C. (2011). Duplication and partitioning in evolution and function of homoeologous $Q$ loci governing domestication characters in polyploid wheat. Proc. Natl. Acad. Sci. USA, 108 (46), 18737-18742.

\section{KVIEŠU SUGU (TRITICUM L.) VĀRPU MORFOLOG̣IJU NOSAKOŠIE GĒNI}

Rakstā apkopota informācija par gēniem, kuri nosaka kviešu vārpu morfoloǵiju. Parādīts, ka mūsdienu molekulārās ğenētikas pētījumi dod iespēju noteikt gēnus ortologus kviešu radniecīgām sugām (mieži, rudzi u.tml.) un atrast tādus gēnus, kuri līdz šim nav tikuši izmantoti selekcijā. Šo gēnu iesaistīšana varētu efektīvi sekmēt jaunu kviešu škiiṇu izveidošanu. 